\title{
A Tribute to Monique Mémet
}

Hommage à Monique Mémet

\section{The editorial board}

\section{(2) OpenEdition}

\section{Journals}

Electronic version

URL: https://journals.openedition.org/asp/7565

DOI: $10.4000 /$ asp.7565

ISSN: 2108-6354

\section{Publisher}

Groupe d'étude et de recherche en anglais de spécialité

\section{Printed version}

Date of publication: 1 November 2021

Number of pages: 1-2

ISSN: 1246-8185

\section{Electronic reference}

The editorial board, "A Tribute to Monique Mémet", ASp [Online], 80 | 2021, Online since 01 November 2021, connection on 05 December 2022. URL: http://journals.openedition.org/asp/7565 ; DOI: https:// doi.org/10.4000/asp.7565

This text was automatically generated on 5 December 2022

All rights reserved 


\title{
A Tribute to Monique Mémet
}

\author{
Hommage à Monique Mémet
}

\section{The editorial board}

1 April 23, 2021. The saddest of all days. The day our dear friend Monique Mémet passed away, after a 20-year war against a cruel, terrible illness. Despite Monique's heroic courage in the face of many hardships, the illness ultimately prevailed. But Monique will live in our hearts forever.

2 Her departure was a shock for France's English for specific purposes (ESP) community. She was widely acknowledged as one of the pioneers of the discipline in French higher education, and a key character of "French ESP" for more than 30 years. After initially serving as a secondary school English teacher, Monique conducted doctoral research on English for electrical engineering, subsequently receiving a Ph.D. from Paris-Sorbonne University in 1994. She then held several positions as a university lecturer in ESP, notably at University Paris 1, and at École normale supérieure de Cachan (ENS), where she served as Head of the Language Department from 2003 to 2008, successfully developing one of France's very few Master's programs in ESP' ${ }^{1}$. While at ENS, she helped many young Anglicists discover ESP. Many of them subsequently pursued doctoral studies in ESP and are today acknowledged academics in this discipline. Monique's many daughters and sons.

3 Monique was a very active member of GERAS, France's learned society for ESP, which she helped structure and prosper throughout the years. She was the holder of all our narratives, all our academic and personal histories, she was the eternal helper, the tireless facilitator, a social networker much before social networks were born. Many ESP projects conducted in France over the past 30 years started from an initial nudge by Monique. All ESP stakeholders in France viewed her as the mainstay of our community. We already miss her so much.

4 A distinguished scientific editor, Monique has been a member of ASp's editorial team for more than 20 years. She very significantly contributed to the academic reputation of this journal, by putting in place our careful review process, enlarging our scientific committee, developing our network of reviewers, establishing a very rigorous reference style, ensuring that the journal was properly indexed in international 
bibliographic databases, and laying the grounds for our ethical statement. When preparing manuscripts for publication, she was the ultimate proofreader, pinpointing the slightest typos or stylistic infelicities. A few years ago, Monique endeavoured to post all ASp articles on our online platform (from previous print versions), a mammoth effort that took more than two years. She was totally determined to position ASp as an internationally acknowledged peer-reviewed publication, always making very useful and constructive suggestions. All the current members of ASp's editorial board were recruited by her, and we have all benefited from her unmatched skills for scientific publication, an exercise in which she always demonstrated rigour, attention to detail, and a taste for perfection. Dear Monique, we owe you so much.

5 Monique would not have approved of a long, detailed tribute. She did not look for medals, titles, or honors. Therefore we shall keep this text short, although we would like to say so many things. Suffice it to say that we will remember Monique as an exceptional human being, an extremely talented colleague, and a role-model for many of us.

6 It is often said that a soldier who gave it all and was ready to make the ultimate sacrifice served "above and beyond the call of duty". No other expression could best describe Monique's courage, commitment and determination, in everything she did, and everything she said. Monique impressed and inspired all of us with her indomitable energy, her unlimited enthusiasm for research, her fiery passion for English studies, and, most of all, her appetite for life.

7 A life that was lived in full, and that will shine as a beacon forever.

\section{NOTES}

1. A joint ENS Cachan / Université Paris-Diderot program. 